\title{
Chiggers and Rickettsia tsutsugamushi from wild rodents of southern Gifu Prefecture, Japan
}

\author{
Sher Afzal Reka, Sahoko Mizuno* and Nobuo Kumada* \\ Department of Medical Zoology, Nagoya University School of Medicine, \\ Nagoya 466, Japan
}

(Received: April 11, 1986)

Key words: trombiculid mite, wild rodent, vector, Rickettsia tsutsugamushi, Gifu Prefecture, Japan.

\begin{abstract}
Surveys of tsutsugamushi disease rickettsia and the vector trombiculid mites were done by trapping wild rodents and other small animals at the southwestern part of Gifu Prefecture during 1980 to 1984 . Eight out of 59 field mice, Apodemus speciosus, were found positive for Rickettsia tsutsugamushi infection. Some of the isolated strains of $R$. tsutsugamushi were examined by complement fixation and partly by immunofluorescent tests; these belonged to Gilliam or Karp types. Two species of probable vectors, Leptotrombidium pallidum and L. scutellare, were found among the 12 species of trombiculid mites collected from the wild rodents. These results indicate that the surveyed area has been potentially endemic with tsutsugamushi disease since the last investigation carried out in 1950's.
\end{abstract}

\section{INTRODUCTION}

Since the last outbreak of tsutsugamushi disease in Japan in 1950's, number of patients of the disease had been decreasing for more than 20 years until the reported cases began to increase in 1976 and thenceforth. According to the annual report of Ministry of Welfare of Japan (Japanese Health and Welfare Statistics Association, 1985), 508, 672 , and 957 cases of tsutsugamushi disease were reported in 1982, 1983, and 1984, respectively. In a recent epidemiological study on tsutsugamushi disease in Gifu Prefecture, antibodies against $R$. tsutsugariushi were detected among healthy people (Kasuya et al., 1985). And in Gifu Prefecture alone 31

\footnotetext{
*シェル・アフザル・レカ, 水野サホ子, 熊田信夫： 名古尾大学医学部医動物学詳座 (干466 名古屋市 昭和区鶴舞 65)
}

and 26 cases of the disease were reported in 1982 and 1983, respectively (Suto, 1983; Kasuya et al., 1984). These recent outbreaks of tsutsugamushi disease in many parts of Japan led us to examine the existing state of vector trombiculid mites and $R$. tsutsugamushi in some known endemic areas in central Japan. This report describes the results of our surveys carried out at the southwestern part of Gifu Prefecture since April, 1980.

\section{Materials and Methods}

Area surveyed: Yoro foothills were selected for the field study. The area is located at the southwestern part of Gifu Prefecture, where the elevation is about $300 \mathrm{~m}$ above the sea level. Most of the trapping sites in this area are sparsely covered by undergrowth and forested with latiferous trees such as 


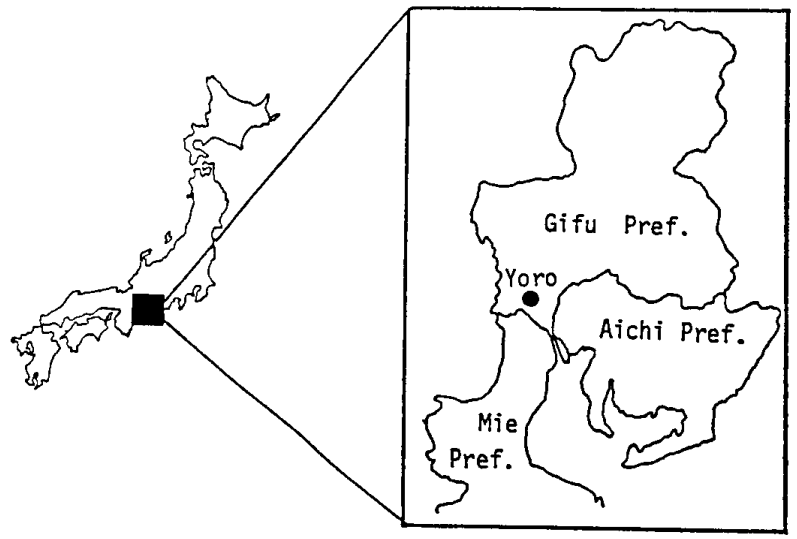

Fig. 1 Location of the surveyed area.

camellias, chestnuts, and oaks, mixed with a few conifers like cryptomeria, white cedars, and pines.

Collection of chiggers: Small rodents and other small animals were captured from their natural habitats in the trapping sites during the period from April 1980 to December 1984.

The animals were captured alive by Sherman box-traps baited with fried fish meat. Captured animals were individually put into polyethylene bags and brought to the laboratory for examination. Then they were kept individually in a small wire cage in a glass funnel, above which a $40 \mathrm{~W}$ electric bulb was lit and under which a Petri dish halffilled with tap water was placed for collecting ectoparasites. The caged animals were fed with pieces of sweet potato, and the ectoparasites detached from the animal and floating on the water were collected with a small painting brush under a stereomicroscope twice daily for at least 5 consecutive days. They were mounted on glass slides with Hoyer's medium and identified microscopically.

Isolation of rickettsia: Most of the rodents except those dead and badly rotten were dissected after the collection of ectoparasites, and the spleen was removed aseptically and homogenized in $1 \mathrm{ml}$ of sucrose phosphateglutamate (SPG) solution, containing 500 units of penicillin $\mathrm{G}$ and $500 \mu \mathrm{g}$ streptomycin per ml. Four week old ICR mice were inoculated intraperitoneally with $0.2 \mathrm{ml}$ of the homogenate.

After 10 days the mice were sacrificed and their spleen homogenates were inoculated into the second group of mice. This procedure was repeated three times using 2 mice in every passage. If any gross sign of rickettsial infection developed, peritoneal smears were prepared to detect rickettsial agents by Giemsa's stain. Mice that did not develop any sign of the infection after the third passage were considered negative. The spleens and livers of rickettsia-positive mice were preserved in SPG solution at $-70^{\circ} \mathrm{G}$ for further studies. Serotypes of the isolates were identified by complement fixation and indirect immunofluorescent tests.

\section{ResUlts}

Small mammals captured during the survey from April 1980 to December 1984 totalled 87. They were composed of 59 Apodemus speciosus Temminck (A.s.), 19 Apodemus argenteus Temminck (A.a.), 3 Eothenomys smithi Thomas (E.s.) and 6 Urotrichus talpoides Temminck (U.t.) (Table 1). The numbers of males and females were approximately equal. The field mice, $A$. s., were the predominant rodent captured in Yoro, comprising $67.8 \%$ of the animals collected. The wood mice, A.a., with a composition rate of $21.8 \%$, were second in dominance. E.s., which are distributed in the southwestern Honshu Island (Tamiya, 1962), were captured only in April 1983 and 1984, comprising the least number in this collection (Table 1).

A total of 6,058 trombiculid mites comprising 5 genera and 12 species were collected in this survey (Table 2). E.s., was found to be a preferable host for trombiculid mites, with a mean number of 299.3 mites per host. A.s., with an average of 71.0 mites per host, was the second preferable host. As indicated in Table 2, Leptotrombidium (Leptotrombidium) fuji (Kuwata et al.) was the most predominant mite, numbering 2,707;90.6\% of which were collected from A.s. L. (Trombiculindus) kansai (Jameson and Sasa) made up the next leading number in this collection, showing a predilection for U.t. L. (L.) pallidum (Nagayo et al.) and $L$. (L.) scutellare (Nagayo et al.) that have been proved to transmit $R$. tsutsugamushi (Asanuma et al., 1962) were collected mostly from $A$.s., the only host from which strains of $R$. tsutsugamushi were isolated. Chatia 
Table 1 Wild mammals captured in Yoro foothills in 1980 through 1984.

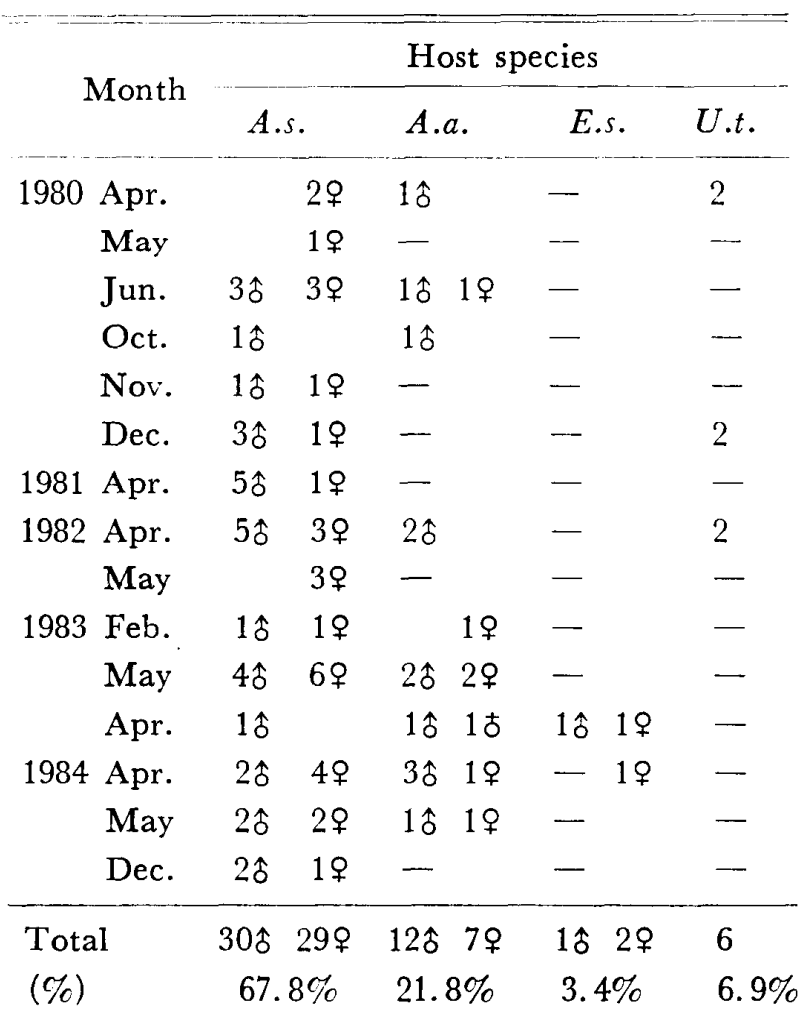

A.s.: Apodemus speciosus, A.a.: Apodemus argeteus, E.s.: Eothenomys smithi, U.t.: Urotrichus talpoides.

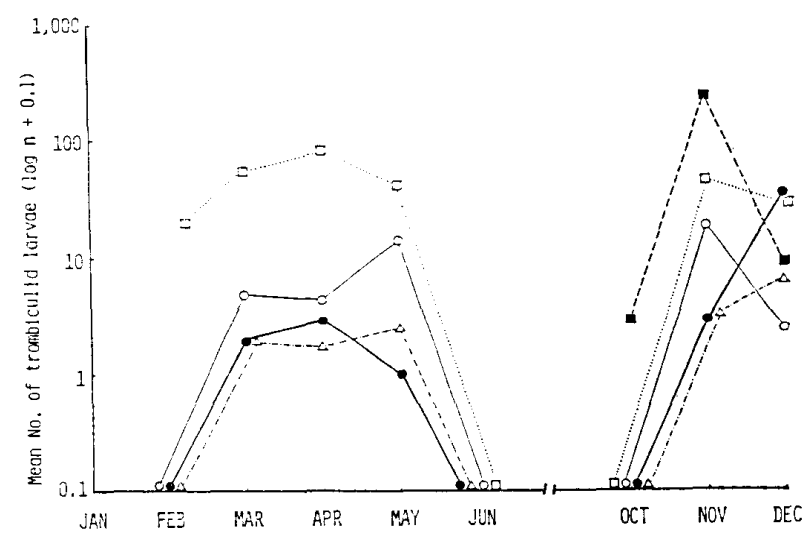

Fig. 2 Trend of seasonal fluctuation of some principal species of larval trombiculid mites found on $A$. speciosus in Yoro.

L. pallidum, $\square$ L. scutellare, $\square$ L. fuji, - L. kitasatoi, $\triangle$ G. saduski.

(Parashunsennia) harunaensis (Kumada) that was found on U.t. in April 1980 was new to Yoro area and Gifu Prefecture.

As indicated in Fig. 2 most of the trombiculid species seemed to disappear in June through September and reappear in fall and early spring. Of the two well known vector species found in this area, L. pallidum were collected in spring and fall, although they were rare in October and November. While, L. scutellare were collected only in October through December, the largest number being

Table 2 Host specificity of trombiculid mites.

\begin{tabular}{|c|c|c|c|c|c|}
\hline \multirow{2}{*}{ Trombiculid mites } & \multicolumn{4}{|c|}{ Host and No. examined } & \multirow{2}{*}{ Total } \\
\hline & A.s. 59 & A.a. 19 & E.s. 3 & U.t. 6 & \\
\hline Leptotrombidium fuji & $2,453(41.6)$ & $47(2.5)$ & $207(69.0)$ & - & 2,707 \\
\hline L. intermedium & $175(2.9)$ & - & $214(71.3)$ & - & 389 \\
\hline L. kitasatoi & $356(6.0)$ & $62(3.3)$ & $153(51.0)$ & - & 571 \\
\hline L. miyajimai & $69(1.2)$ & $4(0.2)$ & $18(6.0)$ & - & 91 \\
\hline L. miyazakii & $15(0.5)$ & - & - & - & 15 \\
\hline L. pallidum & $301(5.1)$ & - & $79(26.3)$ & $2(0.3)$ & 382 \\
\hline L. scutellare & $493(8.3)$ & - & - & - & 493 \\
\hline L. kansai & $25(0.4)$ & - & - & $837(139.5)$ & 862 \\
\hline Neotrombicula ichikawai & $154(2.6)$ & - & - & - & 154 \\
\hline Gahrliepia saduski & $147(2.5)$ & $5(0.2)$ & $227(75.7)$ & - & 379 \\
\hline Cheladonta ikaoensis & $1(0.01)$ & - & - & - & 1 \\
\hline Chatia harunaensis & - & - & - & $14(2.3)$ & 14 \\
\hline Total & $4,189(71.0)$ & $118(6.2)$ & $898 \quad(299.3)$ & $853(142.2)$ & 6,058 \\
\hline
\end{tabular}

A.s.: Apodemus speciosus, A.a.: Apodemus argenteus, E.s.: Eothenomy's smithi, U.t.: Urotrichus talpoides. ( ): mean number per host. 
Table 3 Typing of rickettsia strains isolated from wild rodents.

\begin{tabular}{|c|c|c|c|c|c|c|}
\hline \multirow{2}{*}{$\begin{array}{l}\text { Rickettsia } \\
\text { strains }\end{array}$} & \multicolumn{3}{|c|}{ Immunofluorescent test } & \multicolumn{3}{|c|}{ Complement fixation test } \\
\hline & Karp & Kato & Gilliam & Karp & Kato & Gilliam \\
\hline $\mathrm{Y}-20$ & $\mathrm{NT}$ & N T & NT & - & - & 20 \\
\hline $\mathrm{Y}-22$ & - & - & H & 40 & 40 & 80 \\
\hline $\mathrm{Y}-25$ & H & - & - & 10 & 10 & - \\
\hline $\mathrm{Y}-30$ & - & - & H & - & 20 & 20 \\
\hline$Y-41$ & $\mathrm{NT}$ & NT & N T & 10 & 10 & 20 \\
\hline $\mathrm{Y}-80$ & $\mathrm{NT}$ & NT & NT & 320 & 40 & - \\
\hline
\end{tabular}

Each value: $10 \times 2$ serial dilutions, NT: not tested.

recorded in November.

Strains of $R$. tsutsugamushi was isolated from 8 out of 59 A.s. in February, April and December during the period of this study. None of $A . a$. and E.s. was found to be infected with the rickettsia. U.t. were not tested for rickettsial isolation. When three of the isolated strains of $R$. tsutsugamushi were tested by indirect immunofluorescence method, only Karp and Gilliam strains were identified. Whereas, when tested by complement fixation method six isolates revealed to belong to Karp, Gilliam, or combination of Karp-Kato and Gilliam-Kato strains (Table 3). The virulence of one of the isolated strains (Y-22) was titrated in 4 week old male ICR mice and calculated after the method of Kärber (1931); $\mathrm{LD}_{\tilde{5} 0}$ was estimated to be $10^{-6.1}$.

Another attempt to determine the presence of $R$. tsutsugamushi in L. pallidum larvae collected from the trapped rodents was so far unsuccessful.

\section{Discussion}

During 1950's surveys of tsutsugamushi disease were conducted by several workers (Fujita et al., 1956; Horikawa, 1957; Kuwabara, 1960; Tamiya et al., 1962) along the southern or northern sides of the Yoro mountain range that forms the boundary between Mie and Gifu Prefectures. During that time, patients of tsutsugamushi disease were reported from the southern Mie side of Yoro range (Kuwabara, 1960), but none from the northern Gifu side, although Tamiya et al. (1962) in 1955 to 1958 revealed the existence of vector species as well as patho- genic rickettsia at three spots, namely, Kamiishizu (Yoro), Hagiwara (Mashida), and Hosoe (Yoshiki) in Gifu Prefecture. They also recorded several species of trombiculid mites, including $L$. pallidum and L. scutellare, from Yoro area.

During the period of our survey at Yoro Town, unforeseen occurrence of a patient who died of tsutsugamushi disease was reported in June 1982 from Godo Town, Gifu Prefecture, from where no cases of the disease had ever been known since 1950, when the disease was designated to be notified to the authority. A total of 31 sporadic cases were diagnosed in Gifu Prefecture until the end of 1982, followed by 26 cases in 1983. Furthermore, isolation of $R$. tsutsugamushi from Kani City area in Gifu Prefecture, was reported by Kasuya et al. (1985).

These recent events definitely indicated that natural cycle of pathogenic rickettsia among the vector trombiculid mites and their rodent hosts has extensively been maintained in this district.

Twelve species of trombiculid mites were found from small mammals in Yoro area as shown in Table 2. Despite the predominance of A.s. among the host animals and the number of trombiculid mites found on them, E.s. seemed to be the more preferable host for some species of trombiculid mites, because mean number of mites on E.s. far exceeded that on A.s. However, "host preference" of trombiculid mites might be derived simply from the ecological difference among the rodent hosts and habitats of each trombiculid species as discussed by Audy (1947) and Traub and Wisseman (1974). However, more than $97 \%$ of $L$. (T.) kansai 
were collected from $U . t$., indicating that this insectivore is a favorite host for $L$. (T.) kansai. The least number of mites $(2.0 \%)$ obtained from A.a., may suggest the semiarboreal nature of the host.

Most of the trombiculid species found in the present study were in common with those from the adjacent areas in northern Mie Prefecture reported by Fujita et al. (1956), Horikawa (1957) and Kuwabara (1960), except for Chatia (Parashunsennia) harunaensis that has not been reported from these areas.

Out of 12 species of trombiculids in this collection, L. pallidum and L. scutellare are among the known vectors of scrub typhus in Japan. L. scutellare, which is the known vector of Shichito Fever (Sasa, 1956; Asanuma et al., 1962), was found here only in fall through winter. While, L. pallidum appeared in a longer period from October through May. This confirms the earlier results described by Fujita et al. (1956) in the northern part of Mie Prefecture. Since the last report on the isolation of $R$. tsutsugamushi from the rodents in Kamiishizu Village, western Yoro in 1958 (Tamiya et al., 1962), this is the first report on successful isolation and typing of $R$. tsutsugamushi from the rodent hosts in Yoro area. Isolation of the virulent strains of $R$. tsutsugamushi and the existence of two species of well-known vector mites suggest the high probability of the occurrence of tsutsugamushi disease in this area.

\section{ACKNowledgements}

We are very grateful to Dr. M. Murata, the then instructor of the Department of Immunology, Institute of Medical Science, University of Tokyo, for typing of the isolated rickettsia strains. We also thank to the staff members of our laboratory for their assistance in the field and laboratory works.

\section{REFERENCES}

Asanuma, K., K. Okubo, N. Kumada and M. Kitaoka (1962): Symposium on scrub typhus in Japan. Determination of the vector mites of scrub typhus in Japan. Jpn. J. Med. Sci. Biol., 15: $297-308$.

Audy, J. R. (1947): Scrub typhus as a study in ecology. Nature, 159: 295-296.
Fujita, H., T. Suzuki and T. Horikawa (1956): Epidemiological studies on 20 days fever in Mie Prefecture. Part I: On rickettsia isolation in Mie Prefecture. Mie Med. J., 6: 153-169.

Horikawa, T. (1957): Epidemiological studies on 20 days fever in Mie Prefectures. Mie Igaku, 1: 3-7 (in Japanese).

Japanese Health and Welfare Statistics Association (ed.) (1985): Kokumin Eisei no Doko, 32(9): 416 (in Japanese).

Kärber, G. (1931): Beitrag zur kollektiven Behandlung pharmakologischer Reihenversuche. Arch. Exp. Pathol. Pharmakol., 162: 480.

Kasuya, S., M. Iwasa, A. Hioki, A. Ito, H. Ohtomo, N. Noda, M. Watanabe and F. Yamada (1985): Studies on tsutsugamushi disease in Gifu Prefecture. Part I: Isolation of Rickettsia tsutsugamushi from wild rodents at new area and epidemiological studies on patients and latent patients in the Prefecture. Jpn. Assoc. Inf. Dis., 59: 471-477 (in Japanese).

Kasuya, S., H. Ohtomo, M. Shigemura, E. Shimada, N. Iwata and S. Izumi (1984): Three cases of tsutsugamushi disease found in Tono district in Gifu Prefecture. Clin. Bacteriol., 11: 212220 (in Japanese).

Kuwabara, Y. (1960): Investigation of tsutsugamushi disease in the North of Mie Prefecture. Mie Igaku, 4: 863-878 (in Japanese).

Sasa, M. (1956): Tsutsugamushi and tsutsugamushi disease, 497 pp., Igakushoin, Tokyo (in Japanese) .

Suto, T. (1983): Recent trend of the outbreaks of tsutsugamushi disease in Japan and the present state of etiological diagnosis. Clin. Bacteriol., 10: 139-149 (in Japanese).

Tamiya, T. (ed.) (1962): Recent advances in studies of tsutsugamushi disease in Japan, 309 pp., Medical Culture, Tokyo.

Traub, R. and C. L. Wisseman, Jr. (1974): The ecology of chigger-borne rickettsiosis (scrub typhus). J. Med. Entomol., 11: 237-303.

\section{摘 要 \\ 岐阜県南部の野鼠寄生恙虫と野鼠からの 恙虫病リケッチアの分離}

岐阜県養老町において1980年 4月から1984年 12 月 の期間に野鼠類を捕獲し, 寄生恙虫および恙虫病りケ ッチアの保有の有無について調查した. 捕獲した野生 小動物 3 属 4 種 87 頭のうち, アカネズミ59頭中 8 頭か ら恙虫病リケッチアが分離され，これらは補体結合反 応および一部は間接螢光抗体法によって, 主として Gilliam 型と Karp 型から成ることがわかった。 ま た，5属12種の恙虫が記録され，このなかには恙虫病 媒介種として重要なフトゲツツガムシとタテツツガム 
シの 2 種が含まれていた. なお， ハルナパラシュンセ ンツツガムシ Chatia (Parashunsennia) harunaensis が当地域から初めて記録された，以上の結果から，今
回の調查地域一帯には, 1950年代以後も持続的かつ潜 在的に恙虫病が浸淫しているものと考えられる. 